\title{
Upregulation of microRNA-17-92 cluster associates with tumor progression and prognosis in osteosarcoma
}

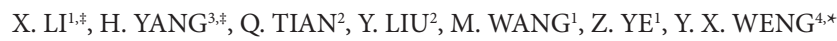 \\ ${ }^{1}$ Department of Orthopedics, The First People's Hospital of Taizhou, Taizhou 318200, China; ${ }^{2}$ Department of Orthopedics, Union Hospital, Tongji \\ Medical College, Huazhong University of Science and Technology, Wuhan 430022, China; ${ }^{3}$ Department of Spine Surgery, The First Affiliated \\ Hospital, Sun Yat-sen University, Guangzhou, 510080, China; ${ }^{4}$ Department of Hand Surgery, Union Hospital, Tongji Medical College, Huazhong \\ University of Science and Technology, Wuhan 430022, China
}

*Correspondence: medorthway@126.com

*Contributed equally to this work.

Received October 15, 2013 / Accepted November 28, 2013

\begin{abstract}
MicroRNA-17-92 (miR-17-92) cluster has been demonstrated to play a crucial role in various human cancers. However, its effects in osteosarcoma have not yet been elucidated. The purpose of this study was to investigate the clinical significance of miR-17-92 cluster in osteosarcoma. MiR-17-92 cluster expression in osteosarcoma clinical samples and cell lines was detected by real-time quantitative RT-PCR. Then, the association of miR-17-92 cluster level with survival of osteosarcoma patients was performed by the Kaplan-Meier and Cox proportional regression analyses. Furthermore, the effects of miR-17-92 cluster on tumorigenicity of osteosarcoma cell lines were evaluated by in vitro assays. The relative expression of miR-17-92 cluster in osteosarcoma tissues was significantly higher than those in adjacent normal tissues $(\mathrm{P}=0.001)$. And there was a relationship between miR-17-92 cluster upregulation and advanced TNM stage of osteosarcoma patients $(\mathrm{P}=0.037)$. Moreover, higher miR-17-92 cluster expression clearly predicted poorer Recurrence-free survival $(\mathrm{P}<0.001)$ and Overall survival $(\mathrm{P}=0.002)$. In the multivariate analysis, high miR-17-92 cluster expression was an independent prognostic factor for Recurrence-free survival $(\mathrm{P}<0.001)$ and Overall survival $(\mathrm{P}=0.002)$. Furthermore, the cellular proliferation, invasion, and migration of osteosarcoma cell lines were significantly accelerated by miR-17-92 cluster plasmid in vitro assays. Our findings showed that miR-17-92 cluster could serve as a promising marker for tumor recurrence and survival of osteosarcoma patients. Moreover, miR-17-92 cluster has been identified as a promoter for tumorigenicity of osteosarcoma cells, thus it might be a critical targeted therapy strategy for osteosarcoma.
\end{abstract}

Key words: MiR-17-92 cluster, osteosarcoma, recurrence-free survival, overall survival, tumor progression, prognosis

Osteosarcoma is the most common primary malignant bone tumor, which typically appeared in children, adolescents and young adults [1]. It mainly occured at the regions with active bone growth and reparation, such as distal femur, proximal tibia and proximal humerus. High metastatic potential is one notorious features of this tumor [2]. The treatment of osteosarcoma is one of the most challenging clinical situations faced by an orthopaedic surgeon, and patients managed with amputation and most patients died of lung metastasis within one year. Owing to the standard combination surgery with neoadjuvant and adjuvant chemotherapy in recent years, the cure rate of osteosarcomas has been dramatically improved $[3,4]$. However, the relative 5 -year survival rate of osteosarcomas is $61.6 \%$ in children and adolescents age under 25 years [5]. Therefore, the identification of effective prognostic biomarkers is urgently needed in order to understand the molecular mechanism of metastasis involved in osteosarcomas, and to predict response possibilities to therapeutic strategies.

MicroRNAs (miRNAs) represent a class of endogenous, highly conserved, single stranded and small nonprotein-coding RNA molecules, whith ranging from 18 to 24 nucleotides in length [6]. MiRNAs are widely expressed in organisms and are mostly located in introns and exons of protein-coding or non-coding RNA genes or in fragile sites [7,8]. And play an important role in the regulation of their target genes expression through a complex process resulting in either the target mRNA degradation or the post-transcriptional level 
inhibition [9]. As such, many miRNAs have been reported to play a pivotal roles in multiple normal biological processes including cell proliferation, differentiation and apoptosis in various types of cancers $[10,11]$. Studies also shown that altered miRNA expression is correlated with the development and metastatic progression of cancer, thus miRNAs could be used as biomarkers for cancer diagnosis, prognosis $[12,13]$. Meanwhile, miRNAs can have tumorigenic or tumor suppressor activities $[14,15]$, suggesting that miRNAs may be used as targets in preventing tumor metastasis.

MiR-17-92, is one of the best characterized polycistronic miRNAs located at chromosome 13q31. The miR-17-92 cluster composed of seven miRNAs (miR-17-5p, miR-17-3p, miR-18a, miR-19a, miR-20a, miR-19b, and miR-92-1) [16,17]. Recent studies have observed that the miR-17-92 cluster is overexpressed in several types of cancer [18-20]. Studies also have shown that overexpression of miR-17-92 cluster may regulate cell cycle, apoptosis, invasion, and proliferation in many types of human cancer $[21,22]$. However, its effects in human osteosarcoma have not been fully elucidated. The aim of this study was to investigate the clinical significance of miR-17-92 cluster in human osteosarcoma.

Table 1. Association between miR-17-92 cluster expression and conventional clinicopathological characteristics in 117 patients with osteosarcoma

\begin{tabular}{|c|c|c|c|c|}
\hline \multirow[t]{2}{*}{ Clinical features } & \multirow[t]{2}{*}{ No. } & \multicolumn{2}{|c|}{ miR-17-92 cluster expression (n, \%) } & \multirow[t]{2}{*}{$\mathrm{P}$} \\
\hline & & Low $(n=45)$ & $\operatorname{High}(\mathrm{n}=72)$ & \\
\hline \multicolumn{5}{|l|}{ Gender } \\
\hline Male & 69 & 25 & 44 & \multirow[t]{2}{*}{0.552} \\
\hline Female & 48 & 20 & 28 & \\
\hline \multicolumn{5}{|l|}{ Age at diagnosis } \\
\hline$<30$ & 53 & 22 & 31 & \multirow[t]{2}{*}{0.537} \\
\hline$\geq 30$ & 64 & 23 & 41 & \\
\hline \multicolumn{5}{|l|}{ Locations } \\
\hline Femur & 55 & 19 & 36 & \multirow[t]{4}{*}{0.870} \\
\hline Tibia & 36 & 15 & 21 & \\
\hline Humerus & 16 & 7 & 9 & \\
\hline Others & 10 & 4 & 6 & \\
\hline \multicolumn{5}{|l|}{ TNM stage } \\
\hline I & 27 & 16 & 11 & \multirow[t]{3}{*}{0.037} \\
\hline II & 53 & 18 & 35 & \\
\hline III & 37 & 11 & 26 & \\
\hline \multicolumn{5}{|l|}{ Pathological Type } \\
\hline Telangiectatic Os & 17 & 7 & 10 & \multirow[t]{3}{*}{0.875} \\
\hline Small Cell Os & 24 & 9 & 15 & \\
\hline Other & 76 & 33 & 43 & \\
\hline \multicolumn{5}{|l|}{ Progression } \\
\hline Yes & 44 & 11 & 33 & \multirow[t]{2}{*}{0.016} \\
\hline No & 73 & 34 & 39 & \\
\hline \multicolumn{5}{|l|}{ Mortality } \\
\hline Death & 52 & 12 & 40 & \multirow[t]{2}{*}{0.002} \\
\hline Survival & 65 & 33 & 32 & \\
\hline
\end{tabular}

\section{Materials and methods}

Patients, tissue samples and ethics statement. This study was approved by the Research Ethics Committee of Union hospital, Tongji Medical College, Huazhong University of Science and Technology and The First Affiliated Hospital of Sun Yat-sen University. All the patients were informed that the patient data from the cases would be submitted for publication and their written informed consent was obtained. According to the ethical and legal standards, all specimens were handled and made anonymous.

Clinical sample selection. This study retrospectively investigated 117 patients (69 men and 48 women) with osteosarcoma who underwent routine curative treatments between May 2000 and Apirl 2008 at Union hospital, Tongji Medical College of Huazhong University of Science and Technology and The First Affiliated Hospital of Sun Yat-sen University. None of the patients investigated had received chemotherapy prior to the surgery. All patients investigated in the study were diagnosed with osteosarcoma, and the diagnosis and the pathological type were confirmed by two pathologists. The fresh human osteosarcoma tissues and paired normal adjacent bone tissues were surgically obtained from each patient. Then all the tissues were snap frozen in liquid nitrogen. All patients were classified according to the Enneking classification [23]. Tumor metastasis was defined based on the clinical, radiological or pathological diagnosis. The clinicopathologic features of the patients with osteosarcoma are summarized in Table 1.

By the end of March 2013, 117 patients in this study were followed up regularly for an average of 36.4 months (range, 1 to 96 months). Fifty-two (44.4\%) cases died of progression of this disease (survival time range 1-44 months, average 14.2 months) and $65(55.6 \%)$ cases were alive since from 1-96 months (average 54.8 months). Chest radiography, serum alkaline phosphatase (ALP) level, erythrocyte sedimentation rate (ESR), C-reactive protein (CRP) levels were checked every 1-6 months postoperatively. And computed tomography scan and/or magnetic resonance imaging scan was used to confirm the diagnosis when the tumor metastasis was suspected.

To investigate the overall survival and the Recurrence-free survival, we defined a time point of 60 months. Overall survival was determined from the date of surgery to either the date of the last follow-up or cancer-related death. Recurrence-free survival was calculated as the time interval from the date of surgery to the day of the appearance of new metastatic lesions. Patients who died from diseases other than osteosarcoma or from unexpected events were excluded.

Cell lines. Two human osteosarcoma cell lines MG-63, US-OS, and one normal human osteoblast cell line hFOB 1.19, were purchased from the cell bank of the Chinese Academy of Sciences (Shanghai, China). These cells were propagated in DMEM (Invitrogen) supplemented with $10 \%$ fetal calf serum (Gibco), 100U/ml penicillin and $100 \mu \mathrm{g} / \mathrm{ml}$ streptomycin 
(Cambrex). All cells were incubated at $37^{\circ} \mathrm{C}$ in humidified $5 \% \mathrm{CO} 2$.

RNA isolation and real-time quantitative RT-PCR. The expression of miR-17-92 cluster in 117 pairs of human osteosarcoma tissues and paired normal adjacent bone tissues, and human osteosarcoma cell lines, was measured by real-time quantitative RT-PCR analysis. Total RNA was extracted from frozen tissues and cells with Trizol reagent (Invitrogen, Carlsbad, USA), then small RNA were isolated and enriched using the mirVana ${ }^{\mathrm{TM}}$ miRNA Isolation Kit (Ambion, Austin, TX, USA) following the manufacturer's instructions. Then the miRNA expression was measured and quantified by using the TaqMan MicroRNA Assays (Applied Biosystems) following the manufacturer's instructions. Only the samples with the OD A260/A280 ratio close to value of 2.0 were analyzed.

For quantitation of miRNA, $10 \mathrm{ng}$ of total microRNA was reverse transcribed using specific miRNA primers. Subsequently the resulting cDNAs were amplified in triplicate according to Taqman MicroRNA Assays protocol (Applied Biosystems, Foster City, CA, USA). The nucleotide sequences of the qRT-PCR primers for the miR-17-92 cluster were as follows: Forward, 5'-CTGTCGCCCAATCAAACTG-3'; and reverse, 5'-GTCACAATCCCCACCAAAC-3' [24]. Expression level of miR-17-92 cluster was calculated by the change in cycle threshold method. GAPDH and RUN6B level were also measured as internal controls for normalization in osteosarcoma tissues and cells respectively.

Cell transfection. The osteosarcoma cells were seeded into 24 -well plates respectively and incubated overnight. When cells were grown to $50-60 \%$ confluence, the transfection of $5 \mathrm{nmol} / 1$ of miR-17-92 cluster plasmid (Invitrogen, Carlsbad, USA) and negative control plasmid (Invitrogen, Carlsbad, USA) were performed using Lipofectamine 2000 (Invitrogen, Carlsbad, USA) according to the manufacturer's instructions.

Cell proliferation assay. Cell survival of human osteosarcoma cell lines was analyzed by using Cell Counting Assay Kit- 8 (CCK-8) (Dojindo Molecular Technologies, Gaithersburg, $\mathrm{MD})$ according to the manufacturer's instructions. Briefly, $5 \times 10^{3}$ cells were starved in serum-free medium for $12 \mathrm{~h}$, then the cells were transfected with plasmids. After 24, 48, 72 and $96 \mathrm{~h}$, the cells were harvested. And $10 \mu \mathrm{l}$ of CCK- 8 solution was added into each well, the cells were incubated for $1 \mathrm{~h}$, and the absorbance of each sample was measured at a wave-length of $490 \mathrm{~nm}$ with the Model 680 Microplat Reader (Bio-Rad, USA) for two times.

Invasion and migration assay. Invasive and migrative assay of cell lines were measured with Matrigelcoated transwell cell culture chambers ( 24 well insert; pore size, $8 \mu \mathrm{m}$; BD Biosciences, Bedford, MA, USA) and non-coated transwell cell culture chambers. $5 \times 10^{4}$ cells were plated into the top chamber and the medium supplemented with $10 \%$ serum as a chemoattractant was added into the lower chamber. The cells were incubated for $20 \mathrm{~h}$ and the non-invading or non-migrating cells on the upper surface of membrane were wiped off by a cotton swab. Cells had invaded or migrated to the lower surface of the membrane were fixed with methanol and stained with Giemsa. The number of invasive or migrative cells was counted in 10 different fields at $200 \times$ magnification. Each experiment was performed in triplicate.

Statistical analysis. SPSS18.0 for Windows (SPSS Inc, USA) was used for statistical analysis. Continuous variables are presented as the mean \pm standard deviation (SD). Group comparisons of clinical datas were performed by the $\chi^{2}$ test or ANOVA. The Kaplan-Meier method was used to evaluate the association of miR-17-92 cluster expression with overall survival and recurrence-free survival, and the resulting curves were compared by the log-rank test. The Cox proportional hazards model was used to investigate independent risk factors with the overall survival and recurrence-free survival. Values of $\mathrm{P}<0.05$ were considered to be statistically significant.

\section{Results}

MiR-17-92 cluster expression in clinical osteosarcoma samples and human osteosarcoma cell lines. The expression levels of miR-17-92 cluster in 117 pairs of human osteosarcoma tissues and paired normal adjacent bone tissues was determined by real-time quantitative RT-PCR. The miR-17-92 cluster expression was significantly higher in osteosarcoma tissues compared with normal adjacent bone tissues (Fig. 1 a, $\mathrm{P}=0.001$ ). In addition, miR-17-92 cluster expression was also detected in two human osteosarcoma cell lines, MG-63, US-OS, and one normal human osteoblast cell line hFOB 1.19. The expression levels of miR-17-92 cluster in MG-63, US-OS cell lines were both significantly higher than those in hFOB 1.19 cells (Fig. $1 \mathrm{~b}$, both $\mathrm{P}<0.01$ ). But there was no significant difference between MG-63, US-OS cell lines in the expression levels of miR-17-92 cluster (Fig. $1 \mathrm{~b}, \mathrm{P}>0.05$ ).

Association between miR-17-92 cluster expression and the clinicopathological features of osteosarcoma. According to the median expression level (7.4, normalized to GAPDH) of miR-17-92 cluster, the 117 osteosarcoma patients were classified into two groups. Seventy-two cases were assigned to the high expression group and 45 cases to the low expression group. The associations between miR-17-92 cluster expression and various clinicopathological parameters of osteosarcoma patients are summarized in Table 1. The patients with high miR-17-92 cluster expression more frequently had advanced TNM stage $(\mathrm{P}=0.037)$ and tumor progression $(\mathrm{P}=0.016)$. And there was no significant difference in gender, age, tumor locations and pathological type between two groups.

Prognostic value of miR-17-92 cluster expression in osteosarcoma patients. To evaluate the prognostic value of miR-17-92 cluster expression in osteosarcoma patients, we defined a time point of 60 months. During this study, 44 patients presented a progression and 73 did not. In patients who progressed, 33 patients $(33 / 44,75 \%)$ had high miR-17-92 cluster expression. And the detailed clinical information of all 117 osteosarcoma patients was reviewed. Using the Kap- 
A

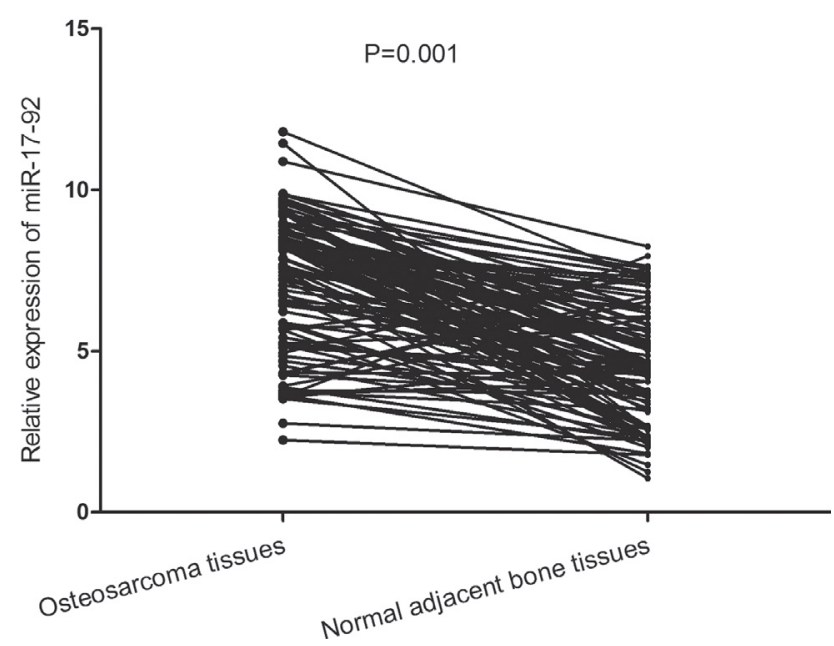

B

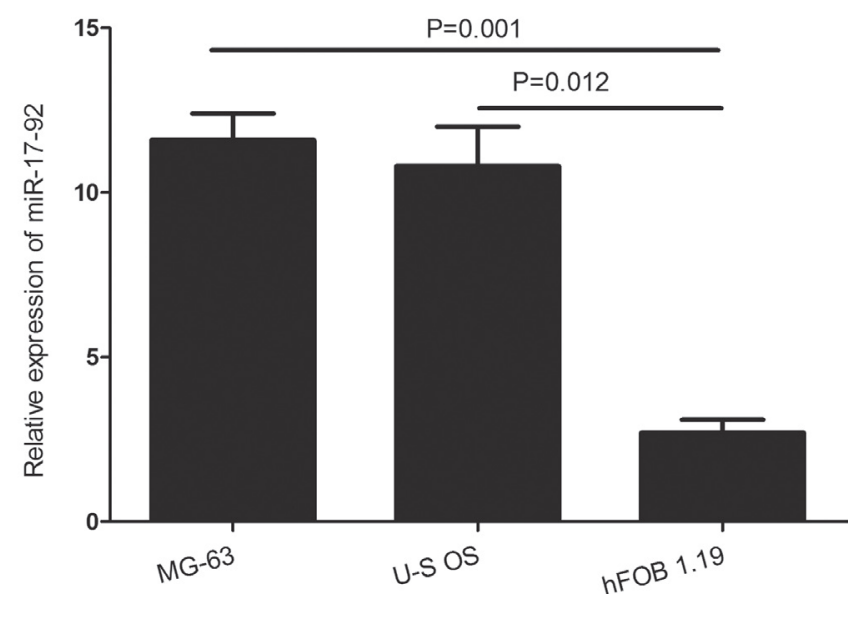

Figure 1. MiR-17-92 is upregulated in osteosarcoma tissues as well as human osteosarcoma cell lines. (a) Levels of miR-17-92 were significantly higher in osteosarcoma compared with paired normal adjacent bone tissues accessed by quantitative RT-PCR. (b) Levels of miR-17-92 in two human osteosarcoma cell lines were both significantly higher than that in hFOB 1.19 cells accessed by quantitative RT-PCR

lan-Meier method and log-rank test, osteosarcoma patients with high miR-17-92 cluster expression were correlated with shorter recurrence-free survival and shorter overall survival (Fig. 2 a, b, Table 2; $\mathrm{P}=0.001$ and 0.002 , respectively) compared with those with low miR-17-92 cluster expression. Moreover, advanced TNM stage (Table 2; both $\mathrm{P}=0.001$ ) was statistically significant risk factor affecting recurrence-free survival and overall survival of patients with osteosarcoma (Table 2), while others were not of predictive values (Table $2, \mathrm{P}>0.05$ ).

In multivariate Cox regression, miR-17-92 cluster and TNM stage were enrolled into the Cox proportional hazard analysis. MiR-17-92 cluster expression (for recurrence-free survival, Hazard Ratio (HR) 3.501, $\mathrm{P}<0.001$; for overall survival: HR
2.941, $\mathrm{P}=0.002$ ) and TNM stage (for recurrence-free survival, HR 1.957, $\mathrm{P}=0.001$; for overall survival, $\mathrm{HR} 2.324, \mathrm{P}<0.001$ ) were both independent prognostic factors for recurrence-free survival and overall survival of patients with osteosarcoma (Table 3).

MiR-17-92 cluster promotes the proliferation of human osteosarcoma cell lines. To evaluate the effects of miR-17-92 cluster on proliferation of osteosarcoma cell lines, osteosarcoma cells were transfected with either miR-17-92 cluster plasmid or negative control plasmid. The miR-17-92 cluster expression in cells transfected with miR-17-92 cluster plasmid were significantly higher than that in cells transfected with negative control plasmid or blank control (Fig. 3). The
A

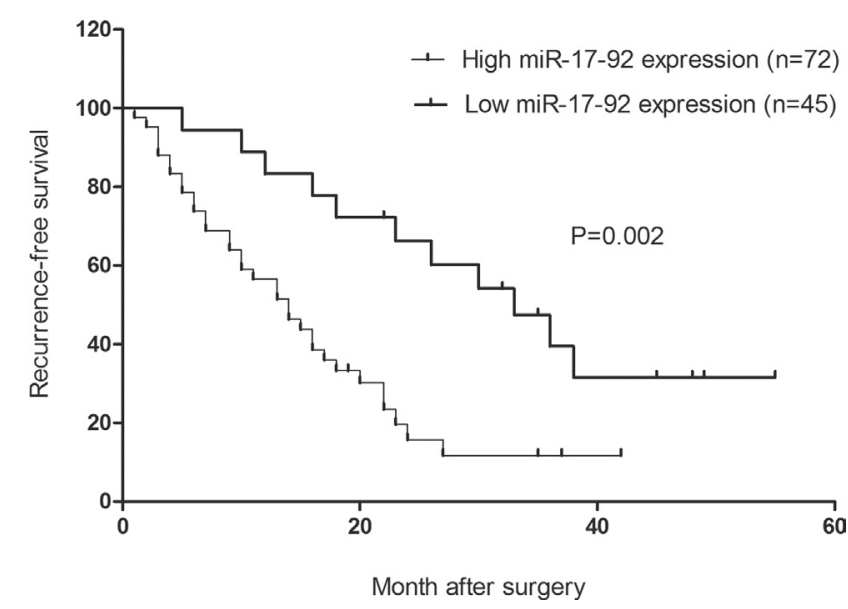

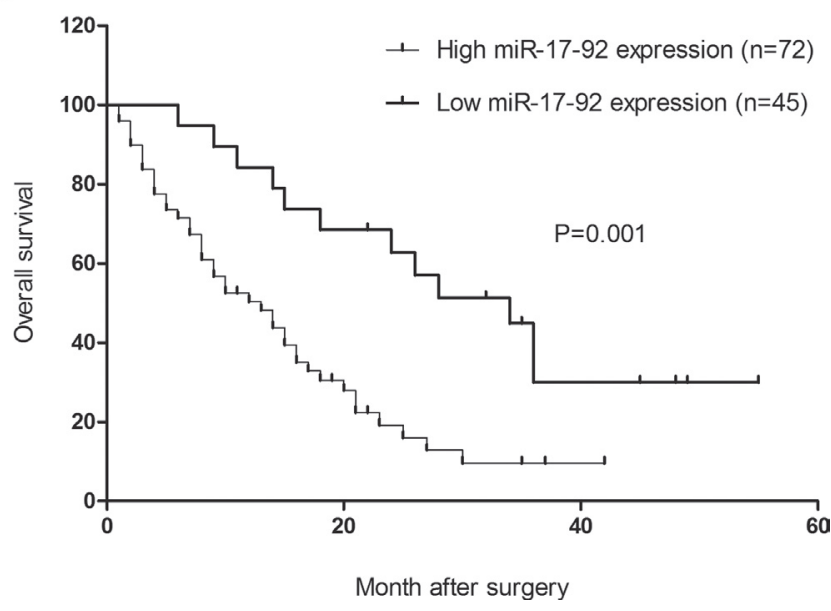

Figure 2. Kaplan-Meier survival curves for osteosarcoma patients according to the expression of miR-17-92. (a) Recurrence-free survival. (b) Overall survival 
A

MG-63

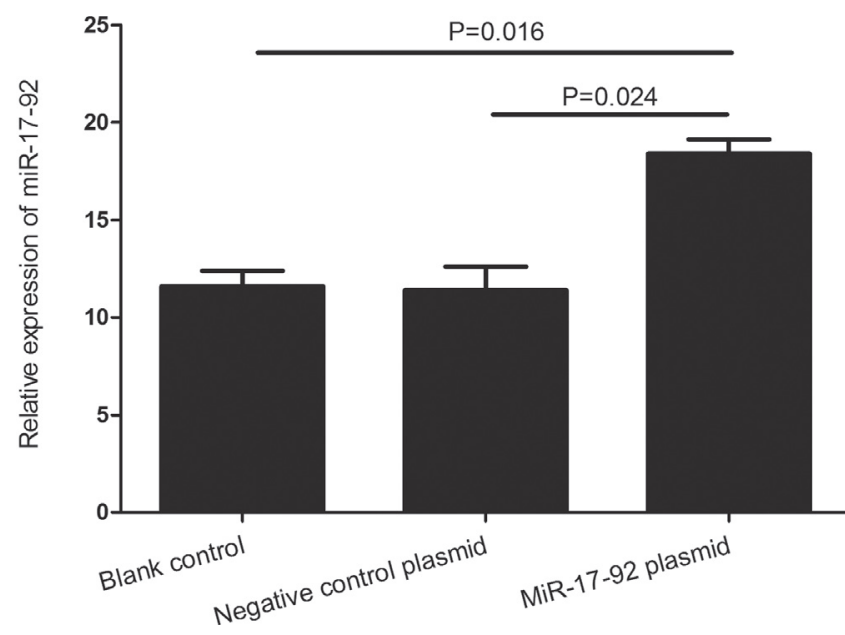

B

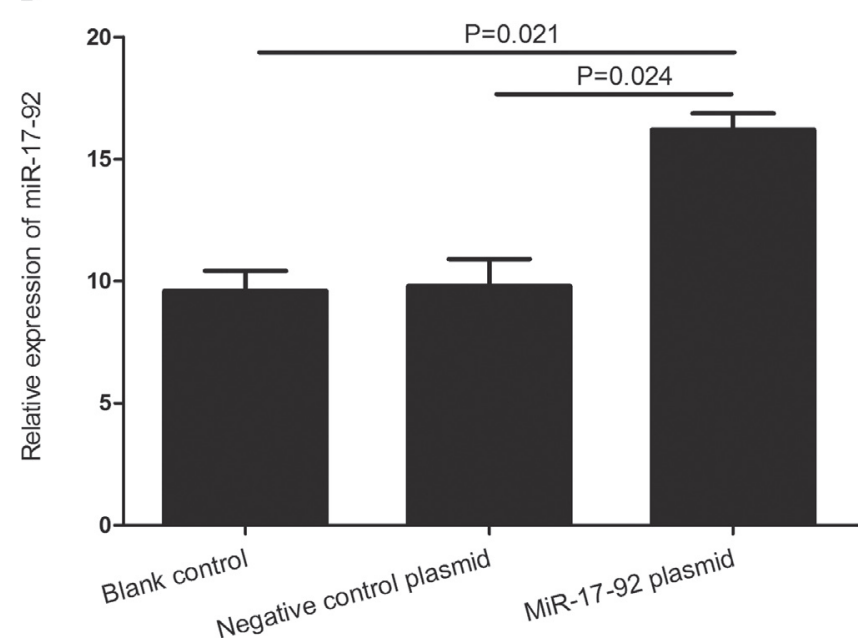

Figure 3. The miR-17-92 expression in MG-63, US-OS cells transfected with miR-17-92 plasmid or negative control plasmid was analyzed by quantitative RT-PCR. The results are presented as mean \pm SD of triplicate experiments

proliferation assay demonstrated that miR-17-92 cluster upregulation significantly promoted the proliferation activity of two human osteosarcoma cell lines (Fig. 4).

MiR-17-92 cluster promotes invasion and migration of human osteosarcoma cell lines. Moreover, the effects of miR17-92 cluster on cell invasion and migration of osteosarcoma cell lines were investigated in vitro. As shown in Fig. 5 and 6 , the overexpression of miR-17-92 cluster had a significant increase in cell invasion and migration of two human osteosarcoma cell lines, MG-63 cells ( $\mathrm{P}=0.004$ and 0.009 , respectively), US-OS cells ( $\mathrm{P}=0.017$ and 0.006 , respectively).

\section{Discussion}

Osteosarcoma is a lethal malignancy of poor clinical outcome when tumors progress to metastasis [1]. Therefore, to search novel therapeutic targets to improve the clinical outcome of osteosarcoma patients is necessary. Previous studies have showed that miRNAs serve as biomarkers and therapeutic targets of treatment response for osteosarcoma $[22,25,26]$. Our work now extends miR-17-92 cluster oncogenic function to osteosarcoma. To our knowledge, this is the first description to investigate the tumorigenic roles of

Table 2. Univariate analysis of the associations of prognosis with various clinicopathological parameters and miR-17-92 expression in osteosarcoma patients

\begin{tabular}{|c|c|c|c|c|c|c|}
\hline \multirow[t]{2}{*}{ Features } & \multicolumn{3}{|c|}{ Recurrence-free survival } & \multicolumn{3}{|c|}{ Overall survival } \\
\hline & $\mathrm{HR}$ & $95 \% \mathrm{CI}$ & $\mathrm{P}$ & HR & $95 \% \mathrm{CI}$ & $\mathrm{P}$ \\
\hline Gender & 0.791 & $0.443-1.413$ & 0.429 & 0.815 & $0.459-1.145$ & 0.487 \\
\hline Age at diagnosis & 0.979 & 0.954-1.004 & 0.099 & 0.985 & $0.960-1.011$ & 0.255 \\
\hline Locations & 1.303 & $0.967-1.756$ & 0.082 & 1.308 & $0.968-1.767$ & 0.080 \\
\hline TNM stage & 2.126 & $1.386-3.261$ & 0.001 & 2.581 & $1.648-4.043$ & $<0.001$ \\
\hline Pathological Type & 1.053 & $0.736-1.507$ & 0.777 & 1.040 & $0.720-1.503$ & 0.833 \\
\hline MiR-17-92expression & 3.477 & $1.728-6.996$ & $<0.001$ & 2.990 & $1.484-6.022$ & 0.002 \\
\hline
\end{tabular}

Table 3. Multivariate analysis of the associations of prognosis with various clinicopathological parameters and miR-17-92 expression in osteosarcoma patients

\begin{tabular}{|c|c|c|c|c|c|c|}
\hline \multirow[t]{2}{*}{ Features } & \multicolumn{3}{|c|}{ Recurrence-free survival } & \multicolumn{3}{|c|}{ Overall survival } \\
\hline & HR & $95 \% \mathrm{CI}$ & $\mathrm{P}$ & HR & $95 \% \mathrm{CI}$ & $\mathrm{P}$ \\
\hline TNM stage & 1.957 & $1.310-2.924$ & 0.001 & 2.324 & $1.530-3.531$ & $<0.001$ \\
\hline MiR-17-92expression & 3.501 & $1.772-6.915$ & $<0.001$ & 2.941 & $1.505-5.747$ & 0.002 \\
\hline
\end{tabular}


A

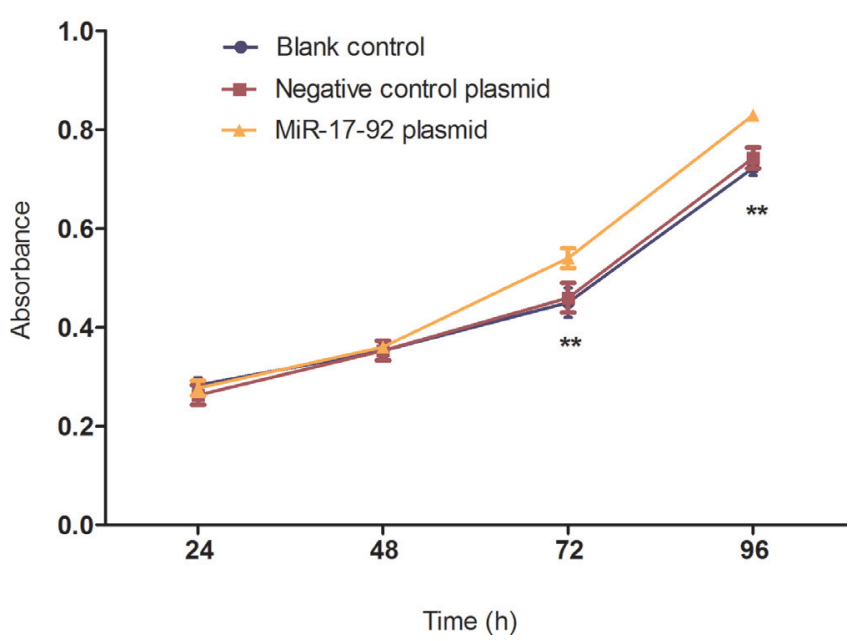

B

U-S OS

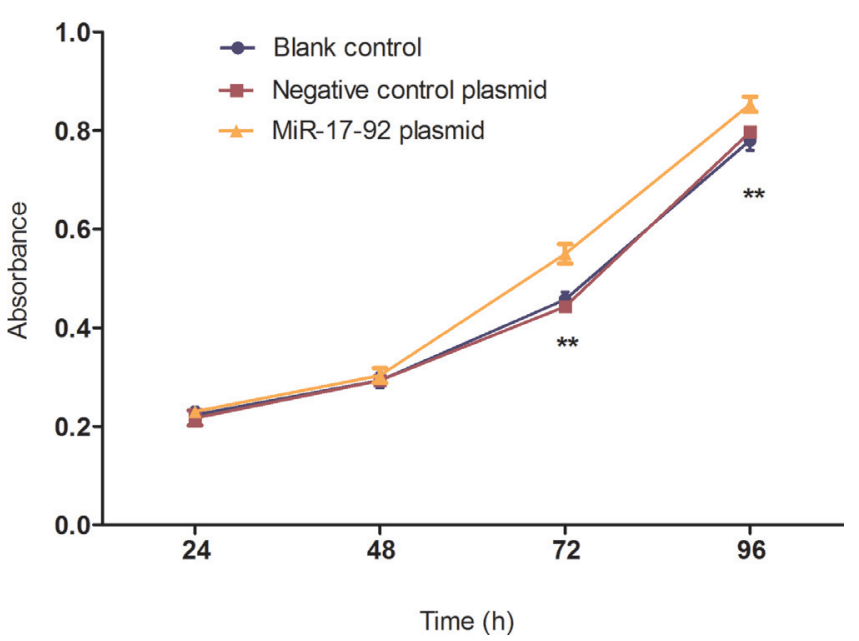

Fig. 4 MiR-17-92 promotes the proliferation of human osteosarcoma cell lines. The proliferation of osteosarcoma cells was determined by the CCK-8 assay at $24,48,72$, and $96 \mathrm{~h}$ after transfection. The results are presented as mean \pm SD of triplicate experiments $\left({ }^{*} \mathrm{P}<0.05\right)$

miR-17-92 cluster expression in human osteosarcoma clinical samples and cell lines.

MiR-17-92 cluster is emerging as a critical oncogenic microRNA cluster in human cancers and is frequently overexpressed in lung cancer, B-cell lymphoma and other tumors [19,27]. In our study, we found that $72(61.5 \%)$ cases of osteosarcoma samples highly expressed miR-17-92 cluster. Especially, the expression levels of miR-17-92 cluster in osteosarcoma tissues and cells were higher than those in adjacent normal bone tissues and normal human osteoblast cell respectively. In addition, patients with high miR-17-92 cluster expression had more frequently advanced TNM stage and tumor progression, indicating that miR-17-92 cluster expression might be of clinical relevance in the aggressiveness of osteosarcoma, which is in keeping with what has been observed previously in several kinds of cancer [28-30].

Furthermore, the relationship between miR-17-92 cluster expression and clinical outcome evaluated by univariate and multivariate analyses, discovered that high miR-17-92 cluster expression was associated with shorter recurrence-free survival and overall survival of patients with osteosarcoma than those with low miR-17-92 cluster expression. Therefore, we
A

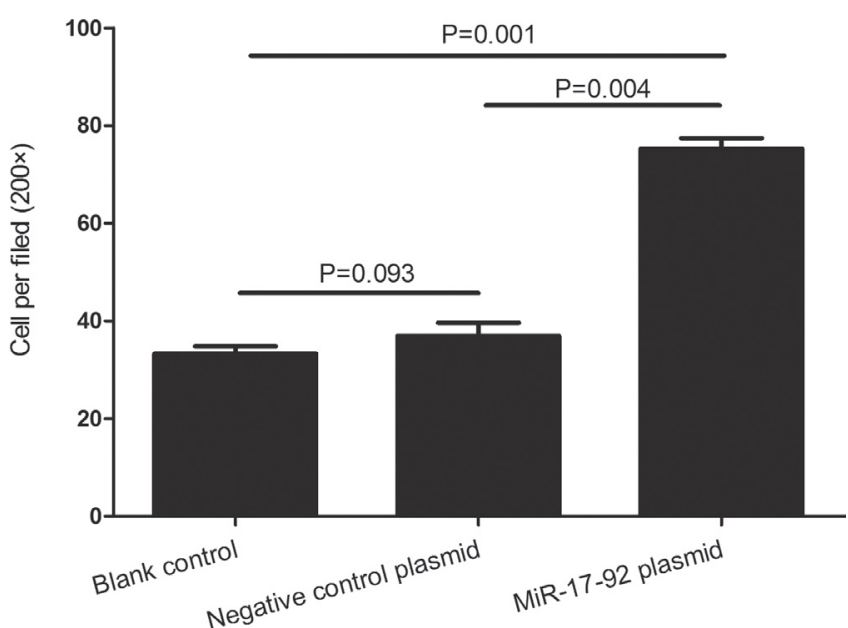

U-S OS

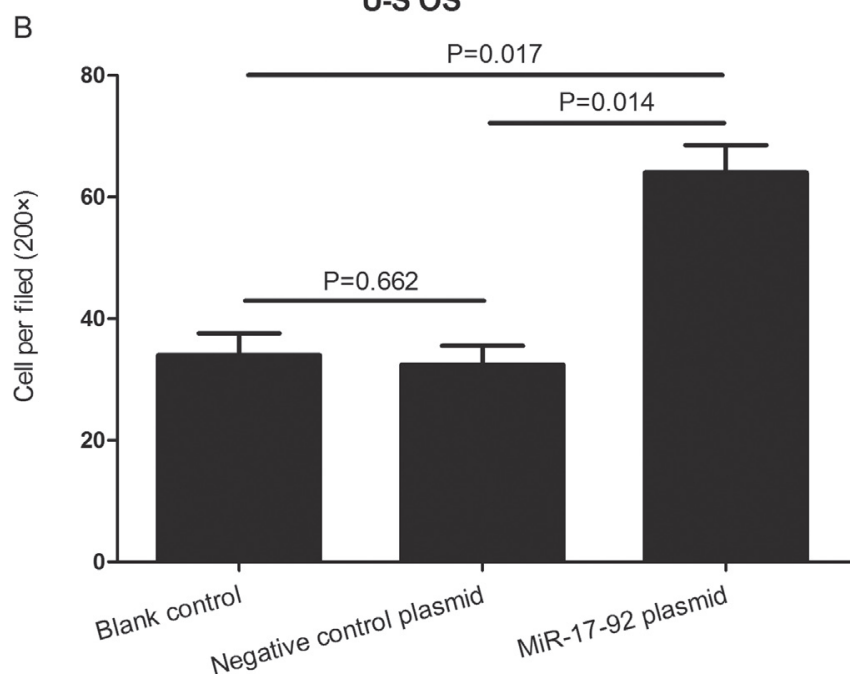

Figure 5. MiR-17-92 promotes the invasion of human osteosarcoma cell lines. The invasion of osteosarcoma cells was determined by the Transwell Matrigel invasion assay after transfection. The results are presented as mean \pm SD of triplicate experiments 
MG-63

A

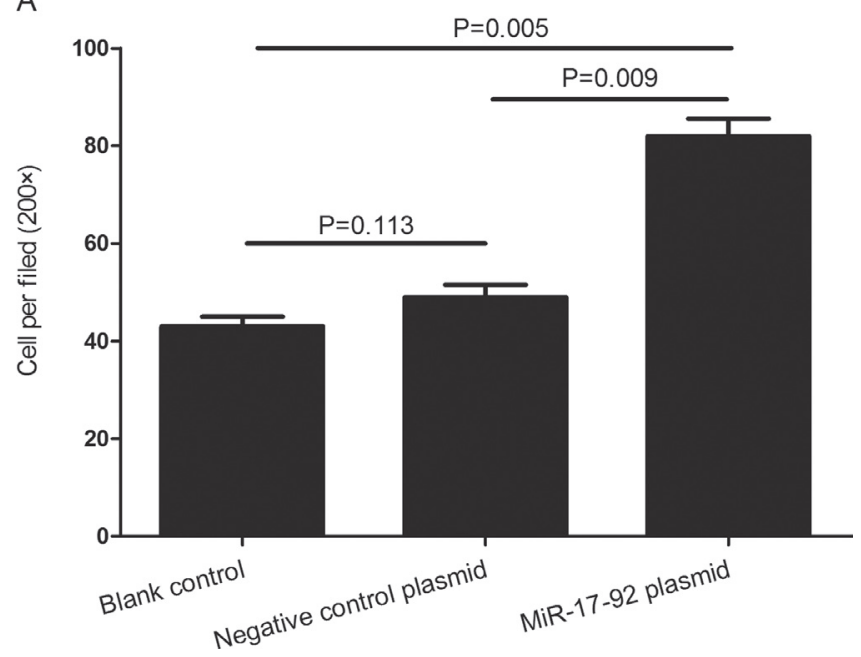

U-S OS

B

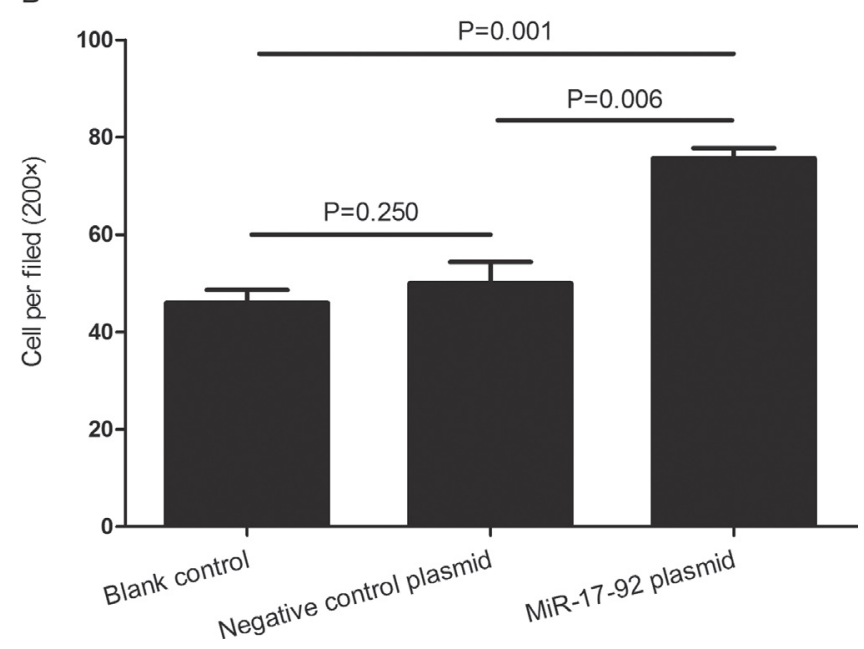

Figure 6. MiR-17-92 promotes the migration of human osteosarcoma cell lines. The migration of osteosarcoma cells was determined by the Transwell migration assay after transfection. The results are presented as mean \pm SD of triplicate experiments

hypothesized that the status of miR-17-92 cluster expression could be an independent factor for predicting the prognosis of this disease. These results were consistent with previous studies in pancreatic cancer and oesophageal squamous cell carcinomas $[31,32]$.

Invasion and metastasis, two of the most important hallmarks of cancer, are the leading causes of lethality in osteosarcoma [1]. In the present study, we demonstrated a significant correlation between the miR-17-92 cluster level and the proliferation, invasion and migration of osteosarcoma cells: the expression of miR-17-92 cluster was higher in cells with higher proliferation, invasion and migration potential. The positive association of miR-17-92 cluster with cell proliferation, invasion and migration suggests that miR-17-92 cluster may be categorized as a "metastasis promotor gene" in osteosarcoma, which was in line with previous reports [22,33,34].

Based on the results of our study, miR-17-92 cluster may serve as a potential therapeutic target for the following findings: First, the expression levels of miR-17-92 cluster in osteosarcoma tissues were significantly higher than those in adjacent normal tissues. Next, high miR-17-92 cluster expression is associated with advanced TNM stage. Then, miR-17-92 cluster may predict the prognosis of patients with osteosarcoma. And finally, miR-17-92 cluster may promote the proliferation, invasion, and migration of osteosarcoma cells in vitro test.

\section{Conclusion}

Together with previous reports, the current observations demonstrate for the first time that miR-17-92 cluster may serve as a potent prognostic marker for tumor recurrence and survival of osteosarcoma patients. On the other hand, we further suppose that the miR-17-92 cluster as a promoter for cell proliferation and tumor progression, suggesting that miR17-92 cluster might thus be a promising therapeutic target for osteosarcoma. However, the mechanism by which miR-17-92 cluster was up-regulated in osteosarcoma is still unclear, and further prospective analysis should be worth doing.

\section{References}

[1] WEBER KL. What's new in musculoskeletal oncology. J Bone Joint Surg Am. 2005; 87: 1400-10. http://dx.doi.org/10.2106/ ఏBJS.E.00257

[2] WALKLEY CR, QUDSI R, SANKARAN VG, PERRY JA, GOSTISSA M, ET AL. Conditional mouse osteosarcoma, dependent on $\mathrm{p} 53$ loss and potentiated by loss of $\mathrm{Rb}$, mimics the human disease. Genes Dev. 2008; 22: 1662-76. http://dx.doi. org/10.1101/gad.1656808

[3] TAN ML, CHOONG PF, DASS CR. Osteosarcoma: Conventional treatment vs. gene therapy. Cancer Biol Ther. 2009; : 106-17. http://dx.doi.org/10.4161/cbt.8.2.7385

[4] KLEIN MJ, SIEGAL GP. Osteosarcoma: anatomic and histologic variants. Am J Clin Pathol. 2006; 125: 555-81. http://dx.doi.org/10.1309/UC6KQHLD9LV2KENN

[5] MIRABELLO L, TROISI RJ, SAVAGE SA. Osteosarcoma incidence and survival rates from 1973 to 2004: data from the Surveillance, Epidemiology, and End Results Program. Cancer. 2009; 115: 1531-43. http://dx.doi.org/10.1002/cncr.24121

[6] AMBROS V. microRNAs: tiny regulators with great potential. Cell. 2001; 107: 823-6. http://dx.doi.org/10.1016/S0092$\underline{\text { 8674(01)00616-X }}$

[7] KIM VN, HAN J, SIOMI MC. Biogenesis of small RNAs in animals. Nat Rev Mol Cell Biol. 2009; 10: 126-39. http://dx.doi. org/10.1038/nrm2632 
[8] BARTEL DP. MicroRNAs: genomics, biogenesis, mechanism, and function. Cell. 2004; 116: 281-97. http://dx.doi. org/10.1016/S0092-8674(04)00045-5

[9] BETEL D, WILSON M, GABOW A, MARKS DS, SANDER C. The microRNA.org resource: targets and expression. Nucleic Acids Res. 2008; 36: D149-53. http://dx.doi.org/10.1093/nar/ gkm995

[10] ESQUELA-KERSCHER A, SLACK FJ. Oncomirs - microRNAs with a role in cancer. Nat Rev Cancer. 2006; 6: 259-69. http://dx.doi.org/10.1038/nrc1840

[11] CALIN GA, CROCE CM. MicroRNA-cancer connection: the beginning of a new tale. Cancer Res. 2006; 66: 7390-4. http://dx.doi.org/10.1158/0008-5472.CAN-06-0800

[12] CUMMINS JM, VELCULESCU VE. Implications of microRNA profiling for cancer diagnosis. Oncogene. 2006; 25: 6220-7. http://dx.doi.org/10.1038/sj.onc.1209914

[13] AHMED FE. Role of miRNA in carcinogenesis and biomarker selection: a methodological view. Expert Rev Mol Diagn. 2007; 7: 569-603. http://dx.doi.org/10.1586/14737159.7.5.569

[14] CALIN GA, CROCE CM. MicroRNA signatures in human cancers. Nat Rev Cancer. 2006; 6: 857-66. http://dx.doi. org/10.1038/nrc1997

[15] ASANGANI IA, RASHEED SA, NIKOLOVA DA, LEUPOLD JH, COLBURN NH, et al. MicroRNA-21 (miR-21) posttranscriptionally downregulates tumor suppressor Pdcd4 and stimulates invasion, intravasation and metastasis in colorectal cancer. Oncogene. 2008; 27:2128-36. http://dx.doi. org/10.1038/sj.onc. 1210856

[16] HE L, THOMSON JM, HEMANN MT, HERNANDOMONGE E, MU D, et al. A microRNA polycistron as a potential human oncogene. Nature. 2005; 435: 828-33. http://dx.doi.org/10.1038/nature03552

[17] BAUMHOER D, ZILLMER S, UNGER K, ROSEMANN M, ATKINSON MJ, et al. MicroRNA profiling with correlation to gene expression revealed the oncogenic miR-17-92 cluster to be up-regulated in osteosarcoma. Cancer Genet. 2012; 205: 212-9. http://dx.doi.org/10.1016/j.cancergen.2012.03.001

[18] TAGAWA H, SETO M. A microRNA cluster as a target of genomic amplification in malignant lymphoma. Leukemia. 2005; 19: 2013-6. http://dx.doi.org/10.1038/sj.leu.2403942

[19] HAYASHITA Y, OSADA H, TATEMATSU Y, YAMADA H, YANAGISAWA K, et al. A polycistronic microRNA cluster, miR-17-92, is overexpressed in human lung cancers and enhances cell proliferation. Cancer Res. 2005; 65: 9628-32. http://dx.doi.org/10.1158/0008-5472.CAN-05-2352

[20] NAMLOS HM, MEZA-ZEPEDA LA, BARØY T, OSTENSEN IH, KRESSE SH, et al. Modulation of the osteosarcoma expression phenotype by microRNAs. PLoS One. 2012; 7: e48086. http://dx.doi.org/10.1371/journal.pone.0048086

[21] LU Y, THOMSON JM, WONG HY, HAMMOND SM, HOGAN BL. Transgenic over-expression of the microRNA miR-17-92 cluster promotes proliferation and inhibits differentiation of lung epithelial progenitor cells.
Dev Biol. 2007; 310: 442-53. http://dx.doi.org/10.1016/ j.ydbio.2007.08.007

[22] HUANG G, NISHIMOTO K, ZHOU Z, HUGHES D, KLEINERMAN ES. miR-20a encoded by the miR-17-92 cluster increases the metastatic potential of osteosarcoma cells by regulating Fas expression. Cancer Res. 2012; 72: 908-16. http://dx.doi.org/10.1158/0008-5472.CAN-11-1460

[23] ENNEKING WF, SPANIER SS, GOODMAN MA. A system for the surgical staging of musculoskeletal sarcoma. Clin Orthop Relat Res. 1980; 153: 106-20.

[24] DEWS M, HOMAYOUNI A, YU D, MURPHY D, SEVIGNANI C, et al. Augmentation of tumor angiogenesis by a Myc-activated microRNA cluster. Nat Genet. 2006; 38: 1060-5. http://dx.doi.org/10.1038/ng1855

[25] HENEGHAN HM, MILLER N, KERIN MJ. MiRNAs as biomarkers and therapeutic targets in cancer. Curr Opin Pharmacol. 2010; 10: 543-50. http://dx.doi.org/10.1016/ j.coph.2010.05.010

[26] JIN Y, PENG D, SHEN Y, XU M, LIANG Y, et al. MicroRNA376c Inhibits Cell Proliferation and Invasion in Osteosarcoma by Targeting to Transforming Growth Factor-Alpha. DNA Cell Biol. 2013; 32: 302-9. http://dx.doi.org/10.1089/ dna.2013.1977

[27] MENDELL JT. miRiad roles for the miR-17-92 cluster in development and disease. Cell. 2008; 133: 217-22. http://dx.doi. org/10.1016/j.cell.2008.04.001

[28] OLIVE V, BENNETT MJ, WALKER JC, MA C, JIANG I, et al. miR-19 is a key oncogenic component of mir-17-92. Genes Dev. 2009; 23: 2839-49. http://dx.doi.org/10.1101/gad.1861409

[29] O'DONNELL KA, WENTZEL EA, ZELLER KI, DANG CV, MENDELL JT. c-Myc-regulated microRNAs modulate E2F1 expression. Nature. 2005; 435: 839-43. http://dx.doi. org/10.1038/nature03677

[30] MESTDAGH P, BOSTROM AK, IMPENS F, FREDLUND E, VAN PEER G, et al. The miR-17-92 microRNA cluster regulates multiple components of the TGF-beta pathway in neuroblastoma. Mol Cell. 2010; 40: 762-73. http://dx.doi. org/10.1016/j.molcel.2010.11.038

[31] YU J, OHUCHIDA K, MIZUMOTO K, FUJITA H, NAKATA $\mathrm{K}$, et al. MicroRNA miR-17-5p is overexpressed in pancreatic cancer, associated with a poor prognosis, and involved in cancer cell proliferation and invasion. Cancer Biol Ther. 2010; 10: 748-57. http://dx.doi.org/10.4161/cbt.10.8.13083

[32] LIU M, WANG Z, YANG S, ZHANG W, HE S, et al. TNF-alpha is a novel target of miR-19a. Int J Oncol. 2011; 38: 1013-22.

[33] YIN R, BAO W, XING Y, XI T, GOU S. MiR-19b-1 inhibits angiogenesis by blocking cell cycle progression of endothelial cells. Biochem Biophys Res Commun. 2012; 417: 771-6. http://dx.doi.org/10.1016/j.bbrc.2011.12.032

[34] CONKRITE K, SUNDBY M, MUKAIS, THOMSON JM, MU D, et al. miR-17 92 cooperates with RB pathway mutations to promote retinoblastoma. Genes Dev. 2011; 25: 1734-45. http://dx.doi.org/10.1101/gad.17027411 